AFRICAN HUMAN RIGHTS LAW JOURNAL

To cite: S Kitharidis 'Rape as a weapon of war: Combating sexual violence and impunity in the Democratic Republic of the Congo, and the way forward' (2015) 15 African Human Rights Law Journal 449-472 http://dx.doi.org/10.17159/1996-2096/2015/v15n2a11

\title{
Rape as a weapon of war: Combating sexual violence and impunity in the Democratic Republic of the Congo, and the way forward
}

\author{
Sophocles Kitharidis* \\ International law consultant, International Affairs Division, Ministry of Justice \\ of the Kingdom of Thailand
}

\begin{abstract}
Summary
Rape is both a consequence and a weapon of war, as may be seen throughout the crisis in the Democratic Republic of the Congo. The United Nations Joint Human Rights Office recently published a report that noted the necessity of moving these issues to the forefront of the international political agenda. Sexual violence in the region has led to mass human rights breaches that require the attention of the international community. With impunity plaguing the social and judicial structure of the DRC, combating this issue is more challenging. This is due to a number of obstacles: a lack of resources within the judicial system; the stigmatisation of victims (social and cultural); the costs of legal proceedings; and a lack of protection for victims. As such, the article examines sexual violence committed by military officers and rebel groups in the DRC in order to outline the failures of the domestic system. It also provides a brief historical overview of sexual violence in the DRC. The article uses Baaz and Stern's perception of 'rape as a weapon of war' to analyse the lack of protection mechanisms for victims and witnesses of sexual violence in the region. In doing so, the article examines the obstacles to fighting sexual violence in armed conflict in the DRC (stigmatisation and shame, and costs of legal proceedings). Finally, the article suggests that a mixed chamber or hybrid court be created in order to prosecute perpetrators of the worst human rights violations.
\end{abstract}

* BA (Hons) LLB (Deakin), LLM (International Law) (Melbourne); sophocles.kitharidis@gmail.com. The author would like to thank the anonymous referees for their comments on earlier drafts. The views expressed and any errors are those of the author. 
Key words: MONUSCO; international criminal law; United Nations; international human rights law; rape; international tribunals; impunity; rule of law

\section{Introduction}

Women in the Democratic Republic of the Congo (DRC) have been the victims of a 'war within a war' ${ }^{1}$ as the number of rapes and other forms of sexual violence soar in the region. Despite numerous attempts to implement peace agreements between warring states and parties, a democratically-elected government, the reformation of laws, a revised constitution, and the presence of the world's largest United Nations (UN) peacekeeping force, ${ }^{2}$ the rule of law in the DRC remains weak. This leaves a deplorable situation concerning sexual violence and, as such, places nearly every woman in the region at risk. Rape is not only a consequence of war, ${ }^{3}$ but also a weapon of war to intimidate local communities and to punish civilians for collaboration with armed military groups. ${ }^{4}$ Specifically, one may argue that rape is enhanced as a tool by military forces to destabilise and humiliate individuals or groups. However, as a result of the 'pervasive and destructive effects of conflict ${ }^{\prime},{ }^{5}$ rape is the product of both armed groups and civilians in the region. ${ }^{6}$ In addition, the United Nations Joint Human Rights Office (UNJHRO) underscores the concept of rape being committed as a 'crime of opportunity alongside other human rights violations" in the DRC.

Moreover, rape cases still escalate at alarming rates, ${ }^{8}$ with Congolese gynaecologist, Dr Dennis Mukwege, stating that 'the word "rape" or "sexual violence" cannot fully translate the horror that

1 Human Rights Watch The war within the war: Sexual violence against women and girls in Eastern Congo (2002); see also J Mantz 'Improvisational economies: Coltan production in the Eastern Congo' (2008) 16 Social Anthropology 34; S Meger 'Rape of the Congo: Understanding sexual violence in the conflict in the Democratic Republic of Congo' (2010) 28 Journal of Contemporary African Studies 119.

2 United Nations Organisation Stabilisation Mission in the Democratic Republic of the Congo (MONUSCO) United Nations Security Council Resolution 1925 (1 July 2010).

3 Office of the High Commissioner for Human Rights (OHCHR) Report of the Panel on Remedies and Reparations for Victims of Sexual Violence in the Democratic Republic of the Congo to the High Commissioner of Human Rights, March 2011, para 142.

$4 \quad \mathrm{OHCHR}$ 'Progress and obstacles in the fight against impunity for sexual violence in the Democratic Republic of the Congo' (April 2014) (UNJHRO Report) 5.

$5 \quad$ As above. See also S Brownmiller Against our will: Men, women and rape (1975).

6 J Mansfield 'Prosecuting sexual violence in the Eastern Democratic Republic of Congo: Obstacles for survivors on the road to justice' (2009) 9 African Human Rights Law Journal 367370.

7 UNJHRO Report (n 4 above).

8 UN News Centre 'New UN statistics show alarming rise in rapes in strife-torn eastern DR Congo' 30 July 2013 http://www.un.org/apps/news/story.asp?NewsID $=45529 \#$.Vjf2adlrKt8 (accessed 31 October 2015); United Nations Office of the High Commissioner for Human Rights 'DRC: Some progress in the fight against 
hundreds of thousands of women are living with in this part of the world' ${ }^{9}$ Alarmingly, he notes that in certain villages, over 90 per cent of women have been victims of sexual abuse. ${ }^{10}$ As such, a plethora of obstacles hamper attempts at combating impunity for sexual violence in the DRC. Aside from the severe lack of resources and human capacity in the judicial system which 'exacerbates impunity', the stigmatisation of victims and a reluctance to pursue the matter further, the high cost of legal proceedings, the lack of protection for victims and witnesses, as well as the increasing dogmatisation and stigmatisation on 'shame' within society also contribute. ${ }^{11}$

The article examines sexual violence committed by military officers and rebel groups in the DRC in order to outline the failures of the domestic system. An examination of recent cases on the issue is undertaken. The article also provides a brief historical overview of sexual violence in the DRC. It uses Baaz and Stern's understanding of 'rape as a weapon of war' to analyse the lack of protection mechanisms for victims and witnesses of sexual violence in the region. In doing so, it examines a number of obstacles when fighting impunity for sexual violence in armed conflict in the DRC (such as stigmatisation and shame, and costs of legal proceedings). Finally, the article suggests a mixed chamber or hybrid court in order to prosecute perpetrators of the worst human rights violations. It provides a comparative analysis of the suggested chamber and the Special Court for Sierra Leone.

\section{DRC and the origins of sexual violence in the region}

The following analysis provides only a brief overview on the history of sexual violence in the DRC as a detailed analysis is beyond the scope of the article. Scholars such as Banwell, ${ }^{12}$ Mantz $^{13}$ and Meger ${ }^{14}$ contend that the genesis of the armed conflict in the region may be traced back to 1998 when 'Africa's World War' occurred. Understanding this conflict may be best interpreted in the context of

impunity but rape still widespread and largely unpunished - UN report' http:// www.ohchr.org/EN/NewsEvents/Pages/DisplayNews.aspx?NewsID=14489\& (accessed 31 October 2015).

9 'Rape as a weapon of war: Accountability for sexual violence in conflict: Hearing before the Sub-Committee on Human Rights and the Law of the Committee on the Judiciary' 110th Congress, 2nd session, 1 April 2008.

10 As above.

11 Mansfield (n 6 above) 370; for a review on 'shame', see K Engle \& A Lottman 'The force of shame' in C McGlynn \& VE Munro (eds) Rethinking rape law: International and comparative perspectives (2010).

12 S Banwell 'Rape and sexual violence in the Democratic Republic of Congo: A case study of gender-based violence' (2014) 23 Journal of Gender Studies 45.

13 Mantz (n 1 above) 34.

14 Meger (n 1 above) 119. 
local conflicts, such as the Rwandan genocide, as well as the Sudanese, Ugandan and Angolan civil wars. ${ }^{15}$ Alliances were formed between rebel forces and government groups which created an 'internal and an international dimension to the conflict'. ${ }^{16}$ Specifically, in 1996 Laurent Kabila overthrew President Mobutu and was supported by the Rwanda Patriotic Army and Uganda's People Defence Force. Working from a position of power, Kabila 'turned his back on Rwanda and Uganda and in 1998, began removing Rwandans from high-ranking positions within his government'. ${ }^{17}$ Such ostracism created hostility and a schism between neighbouring governments and produced multiple attempts to remove Kabila from his position. Due to their inability to remove him from power, Rwanda and Uganda supported anti-government rebel forces in fighting Kabila in Eastern DRC. Groups included the Rassemblement Congolais pour la Démocratie (RCD) and Le Mouvement de Libération du Congo (MLC) and, later on in the attacks, the Forces démocratiques de libération du Rwanda (FDLR) joined in, mainly comprised of Rwandan Interahamwe genocidaires. ${ }^{18}$ Violence continued to expand, with power shifting between the Congolese army, the FDLR and a number of other rebel groups, such as the Mayi Mayi in the Eastern DRC.

In 2002, a peace agreement was signed, instituting a transition government, and general elections in 2006. However, the violence continued. As a result of this occurrence, a second peace agreement was drafted in 2008 and signed by 22 armed groups. This agreement contained instructions for the Congolese government to protect civilians in addition to demonstrating respect towards international humanitarian law and international human rights law. ${ }^{19}$ However, a number of organisations, such as Human Rights Watch, reported that sexual assault continued unabated after the agreement had been signed. ${ }^{20}$ The UNJHRO reported that women were being raped systematically while carrying out chores, working on farms, going to the market and when fetching fresh water. ${ }^{21}$ Alarmingly, from January 2010 to December 2013, more than 3635 cases of sexual assault were reported in the DRC, with the majority of these cases being victims of the Forces Armées de la République Démocratique du Congo (FARDC). ${ }^{22}$ Over 1200 rapes were committed in the context of military operations against armed rebels in North and South Kivu.

15 Banwell (n 12 above) 47.

16 Banwell 48; see also M Chrispin 'Congo rebels to return to talks but not to army' Reuters 8 September 2013.

17 Banwell (n 12 above).

18 As above. See also Mansfield (n 6 above) 372.

19 As above.

20 Human Rights Watch Update on protection of civilians in Eastern Congo's peace process (July 2008)

21 UNJHRO Report (n 4 above) 8.

22 UNJHRO Report 9. 


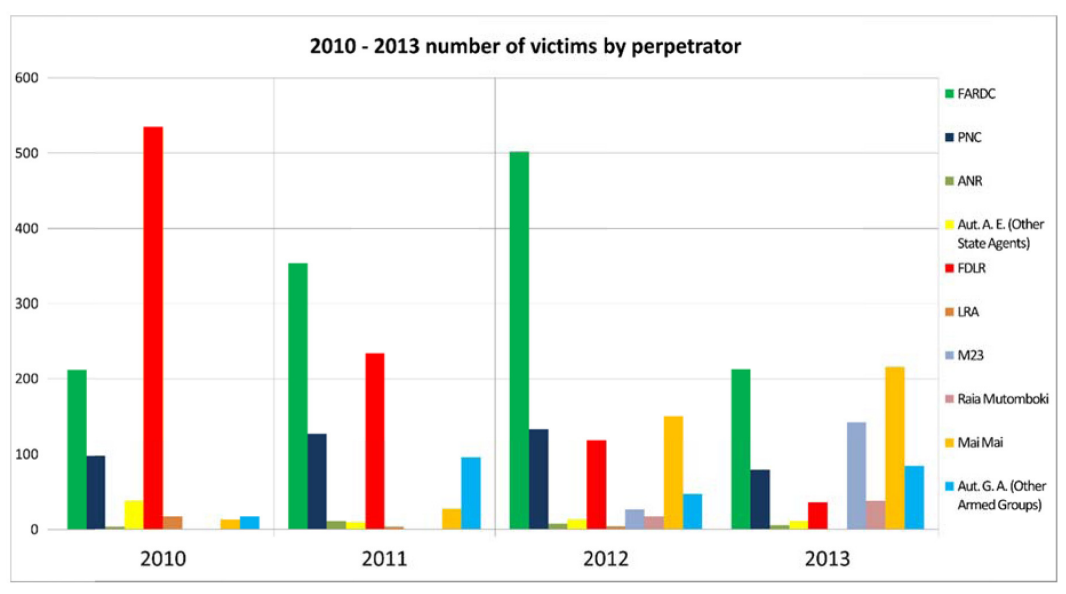

Statistical graph from the United Nations Joint Human Rights Office at the United Nations Organisation Stabilisation Mission in Democratic Republic of the Congo 2010-2013 number of victims by perpetrator ${ }^{23}$

Reports indicate that sexual violence is higher in the conflict regions of North Kivu, South Kivu and Orientale, with rape cases increasing in the last seven years. ${ }^{24}$ The UNJHRO noted that out of the 3635 cases of sexual violence recorded from January 2010 to December 2013 in the DRC, 45 per cent (1 640 victims) were in North Kivu. ${ }^{25}$

\subsection{Presence of international law in Congolese legislation}

The Congolese government's attempt to address rape and sexual violence has been unsuccessful given the alarming rate of rapes still existing in the region. With its legislative obligations to prosecute all cases of sexual violence and with the act being criminalised under domestic Congolese criminal law, ${ }^{26}$ challenges are evident at the domestic level. In addition, given that the DRC is a party to a number of international instruments, such as the International Covenant on Civil and Political Rights (ICCPR) and its Optional Protocol, the International Covenant on Economic, Social and Cultural Rights (ICESCR), the Convention on Elimination of All Forms of Discrimination against Women (CEDAW), the Convention against Torture (CAT) and the Convention on the Rights of the Child (CRC), it is alarming that there is a lack of convictions for rape. In an attempt to combat sexual violence, a number of provisions have been enacted in the Congolese Constitution, including article 14, which expressly urges the state to combat all forms of sexual violence against

23 UNJHRO Report 10.

24 UNJHRO Report 7.

25 As above.

26 UNJHRO Report (n 4 above) 8. 
women, ${ }^{27}$ and article 15 , which defines sexual violence as a crime against humanity. ${ }^{28}$ Within the context of military forces, the DRC has succumbed to enormous pressures to adhere to international rules and regulations concerning the protection of girls and women during peace time and armed conflict. Nevertheless, the 2002 Military Criminal Code is viewed as incompatible with international instruments such as the Rome Statute of the International Criminal Court (ICC) and the Geneva Conventions, because of its failure to incorporate fully into Congolese legislation the criminal law provisions. ${ }^{29}$ It is important to note, however, that the Military Penal Code was amended in 2006 to include protection against sexual violence. $^{30}$ Section II, Title VI and III, Title VI of the Penal Code incorporate provisions that address rape (articles 170-171 (bis)); indecent assault (articles 167-168); enforced prostitution and sexual slavery (article 174(e)); trafficking and exploitation of children for sexual purposes (article 174(j)); forced pregnancy (article 174(k)); enforced sterilisation (article 174(I)); and child prostitution (article 174(n)). The prohibition of spousal rape, however, is not included given the nature of the culturally-tabooed act of reporting such actions. $^{31}$

The FARDC and non-state actors, including UN peacekeepers, have an obligation under international humanitarian and criminal law to

27 Les pouvoirs publics veillent à l'élimination de toute forme de discrimination à l'égard de la femme et assurent la protection et la promotion de ses droits. Ils prennent dans tous les domaines, notamment dans les domaines civil, politique, économique, social et culturel, toutes les mesures appropriées pour assurer le total épanouissement et la pleine participation de la femme au développement de la nation. Ils prennent, des mesures pour lutter contre toute forme de violences faites à la femme dans la vie publique et dans la vie privée. La femme a droit à une représentation équitable au sein des institutions nationales, provinciales et locales. L'État garantit la mise en ceuvre de la parité homme-femme dans lesdites institutions. a loi fixe les modalités d'application de ces droits.

28 Les pouvoirs publics veillent à l'élimination des violences sexuelles sans préjudice des traités et accords internationaux, toute violence sexuelle faite sur toute personne, dans 'intention de déstabiliser, de disloquer une famille et de faire disparaitre tout un peuple est érigée en crime contre l'humanité puni par la loi.

29 Banwell (n 12 above) 52; see also Human Rights Watch 'Seeking justice: The prosecution of sexual violence in the Congo war' March 2005, Vol 17 No 1(A); and OHCHR 'Report of the Panel on Remedies and Reparations for Victims of Sexual Violence in the Democratic Republic of Congo to the High Commission of Human Rights' March 2011.

30 ICRC 'Democratic Republic of the Congo: Practice relating to Rule 93. Rape and other forms of sexual violence' https://www.icrc.org/customary-ihl/eng/docs/ v2_cou_cd_rule93 (accessed 31 October 2015).

31 Canada: Immigration and Refugee Board of Canada Democratic Republic of the Congo: Domestic and sexual violence, including legislation, state protection, and services available to victims (2006-March 2012), 17 April 2012, COD104022.E, http://www.refworld.org/docid/4f9e5e532.html (accessed 3 November 2015). The author argues that because Congolese culture does not recognise spousal rape, women do not report it. 
follow protocol and comply with legislative norms. ${ }^{32}$ Yet, there is a systematic lack of compliance with this obligation. Common Article 3 of the four Geneva Conventions prohibits violence against the life and person as well as insults to personal dignity. ${ }^{33}$

The crime of rape is qualified as a war crime 'both in international and non-international armed conflicts, as well as a crime against humanity in the Rome Statute of the International Criminal Court', 34 to which the DRC has been a party since 2013. Despite the international legal framework that the DRC has adopted, rape and sexual violence go unpunished. As will be explained further below, reasons for this include women's hesitation to report the act; high fees associated with prosecution; difficulties in travelling costs for the victims or witnesses to get to the court; widespread corruption within the legal and judicial system; as well as bribery used to pay judges and political officials to influence the outcome of the trial. ${ }^{35}$ Difficulties also extend to the majority of rape cases not being reported due to fear of retribution as well as victims being stigmatised by the community and therefore feeling shame and guilt. Such social stigma creates a growing barrier between rape and the sexual act, and ends in impunity. These elements are examined below.

\section{Rape as a weapon of war: Obstacles faced by the sexually-abused}

The classification and conceptualisation of sexual violence in the DRC as a 'weapon of war' have merit and place this issue high on the security agenda. Baaz and Stern underscore the importance of the distinction when classifying rape within the DRC context by placing an emphasis on the trends of rape being 'committed against any woman in general regardless of political or ethnic affinity with the perpetrator'.36 Rape in this context is used as a military strategy by rebel forces in order to humiliate and intimidate. Baaz and Stern argue that the DRC's case demonstrates that 'while sexual and other violence is often used to humiliate and intimate, this humiliation and intimidation is also much less strategic and much more complex than

32 UNJHRO Report (n 4 above) 7; see also BF Klappe 'The law of international peace operations' in D Fleck (ed) The handbook of international humanitarian law (2013) 611 617; and PV Sellers The prosecution of sexual violence in conflict: The importance of human rights as a means of interpretation (2006).

33 UNJHRO Report (n 4 above) 7.

34 Banwell (n 12 above) 52.

35 Banwell 53.

36 ME Baaz \& M Stern Understanding and addressing conflict-related sexual violence (2010) 1. 
a combat strategy to further military/political objectives'. ${ }^{37}$ When examining sexual violence in this context, several factors must be explored. These factors include (i) understanding the high levels of violence against civilians in light of the present circumstances of state security; (ii) the existence of a weak justice and penal system and widespread impunity; and (iii) rape occurring in the context of certain militarised ideals of masculinity and sexuality. These factors are critiqued in the analysis below.

\subsection{The justice system and combating widespread impunity}

A continuously weak justice and penal system ${ }^{38}$ has contributed to the widespread violence and rape in the region. The UNJHRO noted that efforts had been made by the Congolese authorities to arrest and try alleged perpetrators of sexual violence. However, despite their efforts, such perpetrators rarely reached the court. ${ }^{39}$ The majority of cases are rarely investigated and when investigations do take place, trials are not held or sentences are not served. The UNJHRO underscores the critical concern of the impunity 'enjoyed by a number of high-ranking officers alleged to be responsible for crimes of sexual violence' ${ }^{40}$ Proceedings on rare occasions target higher-ranking FARDC officers, although the cases are corrupted by judicial and political officials. Those convicted and imprisoned are provided with grounds of escape 'due to the dilapidated conditions and poor security in prisons across the country'. ${ }^{41}$ Baaz and Stern go further to emphasise the impunity brought about by state security personnel. The UNJHRO noted this element and reported on concerns about the shortcomings in investigations into cases by FARDC personnel. The lack of resources and human capacity in the judicial system contributes to an increase in impunity and other obstacles in the 'fight against impunity include[ing] the stigmatisation of victims and their reluctance to pursue justice in the courts' ${ }^{42}$ Further, there is a preference by victims to resort to 'out-of court settlements, which tend to be perpetrator-centred and generally ignore the needs of the victim' ${ }^{43}$ In addition, there are difficulties where victims in the region cannot afford the legal fees and the travelling expenses associated

37 As above. See also 'Report of the Investigation Missions of the United Nations Joint Human Rights Office into the Mass Rapes and Other Human Rights Violations Committed in the Villages of Bushani and Kalambahiro, in Masisi Territory, North Kivu, on 31 December 2010 and 1 January 2011' 22 July 2011.

38 Report (n 37 above) 331.

39 UNJHRO Report (n 4 above) 13.

40 As above. See also R Lincoln 'Recent developments rule of law for whom? Strengthening the rule of law as a solution to sexual violence in the Democratic Republic of the Congo' (2013) 26 Berkeley Journal of Gender, Law and Justice 139 143.

41 As above.

42 UNJHRO Report (n 4 above) 16.

43 As above. See $\mathrm{N}$ Henry 'Witness to rape: The limits and potential of international war crimes trials for victims of wartime sexual violence' (2009) 3 International Journal of Transitional Justice 114. 
with legal proceedings. ${ }^{44}$ Access to justice is, therefore, one of the most prevalent obstacles faced by Congolese women.

A number of challenges exist in the DRC's judicial and legal framework. This analysis will be done later in the article when an examination of a possible tribunal will be conducted. In the DRC there are few protection programmes for victims and witnesses under national law, with no specific unit working on this issue. ${ }^{45}$ In addition, there is a lack of legal provisions criminalising intimidation and threats made against victims of sexual violence. Under article 74bis of the Sexual Violence law, there is a requirement for judicial officers to adopt appropriate measures to provide security, physical and mental wellbeing as well as privacy and dignity to victims of sexual violence or those involved in the trials themselves. The UNJHRO, however, noted that judges were unwilling to take every measure to protect victims or those involved and, as such, the United Nations Team of Experts on the Rule of Law and Sexual Violence in Conflict have been petitioned to assist national efforts to establish appropriate protection mechanisms for victims and witnesses. ${ }^{46}$ The UN's activity in this sphere is contributing towards the improvement of combating impunity and establishing a comprehensive and effective structure. Social stigma placed on rape victims is also a central element for widespread impunity and, because of this, victims are often ostracised by their families and communities. This causes Congolese victims to remain silent to avoid further victimisation, humiliation, social incrimination or the withdrawal of economic support. ${ }^{47}$ The UNJHRO argues that '[s]hifting the stigma from the victims to the perpetrators would have a huge impact on the ability of victims to reclaim their dignity and rebuild their lives'. ${ }^{48}$

Furthermore, the fight against impunity for sexual violence in the DRC lacks the necessary law enforcement institutions. A lack of infrastructure and resources within the military jurisdictions presents a major obstacle to holding alleged perpetrators of sexual violence accountable. One may also argue that prosecutors and magistrates lack the financial and operational means of conducting proper trials and investigations when interviewing victims and witnesses. In addition, and what is of more concern, is the fact that a number of judicial authorities lacks the necessary knowledge when assessing the

44 Banwell (n 12 above) 52.

45 As above.

46 UNJHRO Report (n 4 above) 8. See also OHCHR 'Democratic Republic of the Congo - 1993-2003', Report of the Mapping Exercise Documenting the Most Serious Violations of Human Rights and International Humanitarian Law Committed within the Territory of the Democratic Republic of the Congo between March 1993 and June 2003 (August 2010).

47 As above. See also Mansfield ( 6 above) 386.

48 UNJHRO Report (n 4 above) 22. 
2006 laws on sexual violence, as well as skills to prosecute such crimes. ${ }^{49}$ The lack of comprehensive, well-framed judicial and correctional structures (and infrastructures) has led to many concerns, not only about the country's questionable judiciary being able to successfully prosecute or provide a just legal system, but also about detention and imprisonment facilities. The lack of infrastructure in prisons as well as insufficient security (and security frameworks) have led to several prison breaks involving a number of high-ranking officials, including Lieutenant-Colonel Félix Djela (alias Bravo Tango) from the FARDC, who escaped with other military inmates from Bukavu. $^{50}$ Such crimes constitute critical obstacles to the DRC's justice system, contributing to impunity in the region.

Further, the issue of corruption is one of the most fundamental obstacles identified by rape victims. Paradoxically, this notion is not considered an issue by the judiciary. Corruption appears to take two forms. The first is where litigants pay court officials in order to have the matter heard. ${ }^{51}$ A non-governmental organisation (NGO) worker stated: 52

You need money for the folder to progress [through the judicial proceedings] ... How do you apply pressure for this to happen if you have nothing? For someone to listen to the case, he needs to have something in his stomach.

This notion, therefore, may be viewed as a failure by the state to adequately finance its judiciary. The UN reports that monthly salaries range from US\$13 for a domestic magistrate to US $\$ 30$ for a senior Supreme Court judge, with the report noting that some judges had to wait years to receive small advances. ${ }^{53}$ The public accuses judges of creating obligatory costs to supplement their annual salaries. Complainants are obliged to pay for a number of things in order to secure the attendance of the perpetrators.

The second form of corruption is that of influencing the court's decision. This prevents potential litigants from prosecuting the rapist.

Identifying the perpetrator is also noted as an issue. ${ }^{54}$ This depends on whether the perpetrator is military or civilian. Although there has been an increase in civilians raping women, the majority of rape cases are identified as being committed by armed groups. ${ }^{55}$ Military prosecutions are considered to be rare in the judicial system due to difficulties in securing the arrest of the convicted. This is because a

49 UNJHRO Report 19.

50 UNJHRO Report 20.

51 Mansfield (n 6 above) 400.

52 As above. See also interview with Richard, member of Association de Secours auz Jumeaux et Leurs Parents en Detresse (ASJPD) in Mansfield ( $\mathrm{n} 6$ above).

53 As above.

54 Mansfield ( $\mathrm{n} 6$ above) 389.

55 UNJHRO Report (n 4 above); see also Human Rights Watch 'Democratic Republic of Congo: Ending impunity for sexual violence - New judicial mechanism needed to bring perpetrators to justice' 10 June 2014. 
number of military rapes occur at night with the perpetrators emerging from the bush. ${ }^{56}$ The victims have no choice but to view these people as unknown individuals, identifying them simply by their uniform. In addition, it is more difficult to convince a perpetrator belonging to a rebel force or armed group to appear before a court. ${ }^{57}$ One may, therefore, argue that it has no merit to commence proceedings against soldiers such as those from the FDLR as 'they are impervious to the Congolese legal system' ${ }^{58}$ Military commanders also protect their soldiers, with the International Crisis Group reporting that in the region, even the police were guilty of sexual violence. However, they did not appear in court. ${ }^{59}$ Disturbingly, no military judge may hear a case in which a superior-ranked officer is accused.

\subsection{Civilian violence and militarised masculinity}

Rape is viewed in the context of militarised ideals of masculinity and sexuality common in most military institutions, including those of the DRC. Baaz and Stern argue that the male soldier's libido is described as a 'natural, virile and potent force, which ultimately requires sexual satisfaction from women'. ${ }^{60}$ They contend that it is these ideals that contribute to an environment where sexual violence is considered the norm. ${ }^{61}$ Scholars such as Hooper, ${ }^{62}$ Canning, ${ }^{63}$ Meger, ${ }^{64}$ Zurbriggen $^{65}$ and Leatherman ${ }^{66}$ emphasise this notion by underscoring the idea that men and boys develop a sense of masculinity and violent behaviour when in the military because of specially-designed programmes that aim at fighting and killing. ${ }^{67}$ Such militarised masculinity and heterosexuality is required to be interpreted as 'institutionalised and globalised phenomena' ${ }^{68}$

56 As above.

57 As above. See also Human Rights Watch DR Congo: Peace accord fails to end killing of civilians (July 2008).

58 Mansfield (n 6 above) 390.

59 International Crisis Group 'Congo: Five priorities for a peacebuilding strategy' (African Report 150) (2009) 5.

60 Baaz \& Stern (n 37 above) 2.

61 As above.

62 C Hooper Manly states: Masculinities, international relations and gender politics (2001).

63 V Canning 'Who's human? Developing sociological understandings of the rights of women raped in conflict' (2010) 14 The International Journal of Human Rights 849.

64 Meger (n 1 above).

65 E Zurbriggen 'Rape, war, and the socialisation of masculinity: Why our refusal to give up war ensures that rape cannot be eradicated' (2010) 34 Psychology of Women Quarterly 538.

66 J Leatherman Sexual violence and armed conflict (2011).

67 Banwell (n 12 above) 51.

68 As above. 
Further, Ohambe argues that the soldiers in armies and the military, mainly young men, are usually individuals who lack education, and who live in extreme poverty. ${ }^{69}$ Such individuals also have a lack of alternative employment opportunities and, as such, view the military as a way of gaining 'an income and of acquiring social promotion and power' ${ }^{70}$ Baaz and Stern, as well as Banwell, explore these situations through the DRC's FARDC, and they conclude that soldiers 'relied heavily on construction of masculinity (and femininity)' which were 'formed and reinforced within the military institution' ${ }^{31}$ One may, therefore, argue that the motive or ideal which the Congolese military used to reinforce their notion of rape and sexual violence was that of the heterosexual, potent male fighter. ${ }^{72}$ In this context, the sexual desires and needs of the military are viewed and accepted as 'natural driving force[s] which required "satisfaction" from women whose role it is to satisfy these needs'. ${ }^{\prime 7}$

Furthermore, when interpreting the gender element of sexual violence in the DRC, it is crucial to note that Congolese custom views women as 'disproportionately disadvantaged socially and economically', ${ }^{74}$ even though the literacy rate of males is lower. This also extends to women in positions of power, which is rarely seen in the region, and such a gender bias is reflected in Congolese law. Ohambe argues that in the DRC, in order for a woman to open a bank account, the husband's consent is necessary. Such gender bias also extends to the purchase and sale of land or property, as well as finding employment. ${ }^{75}$ Gender differences are, therefore, encouraged by Congolese society and this, in turn, creates the divide that increases the 'right' of Congolese males to rape females. Brownmiller discusses a similar notion about the mentality of men, arguing that a man's structural capacity to rape and woman's corresponding structural vulnerability are as basic to the physiology of both sexes as the primal act of sex itself. ${ }^{76}$ Her argument is that sexual violence is nothing more than a continuous process of intimidation by which men force women into a state of fear, and contributes to a man's discovery of his genitalia serving as a weapon. ${ }^{77}$

69 MCO Ohambe et al 'Women's bodies as a battleground: Sexual violence against women and girls during the war in the Democratic Republic of Congo, South Kivu (1996-2003)' (2005) Réseau des Femmes pour un Développement Associatif, Réseau des Femmes pour la Défense des Droits et la Paix International Alert. See also Banwell (n 12 above) 51.

70 Banwell (n 12 above) 51.

71 As above.

72 ME Baaz \& M Stern 'Why do soldiers rape? Masculinity, violence and sexuality in the armed forces in the Congo' (2009) 53 International Studies Quarterly 495505.

73 As above.

74 Banwell (n 12 above) 52.

75 As above.

76 Brownmiller (n 5 above).

77 Brownmiller 22. 
Within academic discourse, distinctions are made between masculinity and femininity and their implications for sex. To an extent, war and its psychological effects allow males to have contempt for women, and this is because of the 'brute power of weaponry exclusive to [men's] hands, the spiritual bonding of men at arms, the manly discipline of orders given and orders beyond, the simple logic of hierarchical command'. ${ }^{78}$ When examining the DRC from a genderdiscriminatory perspective, one may argue for the position taken by Brownmiller that the 'winning side is the side that does the raping'. Contributing this to two reasons, Brownmiller notes that 'a victorious army marches through the defeated people's territory, and thus it is obvious that if there is any raping to be done, it will be done on the bodies of the defeated enemy's women' and, second, 'rape is the act of a conqueror'. ${ }^{79}$ Such a theory, however, may be challenged based on the factual scenarios in the DRC. The attacks described by the UNJHRO report challenge the 'victorious' scenario theory, since a number of these cases occurred whilst soldiers were either fleeing or retreating from the front lines due to losses. The UNJHRO, in its 2014 report, outlined the following cases:

(1) During the period between 30 July and 2 August 2010, 387 people were raped by a coalition of FDLR, Mayi Mayi combatants, and combatants of Colonel Emmanuel Nsengiyumva in 13 villages found along the Mpofi-Kibua axis, the Walikale territory, North Kivu province. ${ }^{80}$ Here, it is important to note that one of the armed leaders who assisted in the preparation of the attack on these districts was the Mayi Mayi Sheka leader, Sheka Ntabo Ntaberi, who stood as a candidate in the National Assembly in the Walkikale electoral district in November 2011. As may be seen, this was an orchestrated attack by a number of rebel forces.

(2) Between 31 December 2010 and 1 January 2011, the UNJHRO reported that at least 46 women and one girl were sexually abused by armed men who were believed to be from the FARDC, in the villages of Bushani and Kalambahriro in North Kivu province. On the instructions of the UNJHRO, Congolese authorities attempted to bring the perpetrators to justice. However, the military prosecutor's file was a total failure with the North Kivu justice authorities not proceeding with the investigation.

(3) The UNJHRO noted the sexual violence occurring between 9 and 25 June 2011 in Mutongo and the surrounding villages, Walikale territory, North Kivu province, during fighting between Mayi Mayi and APCLS combatants. It was reported that at least 80 people, including 12 young girls and a man, were raped or had sexual violence performed on them (in addition to other human rights violations being committed). The report noted that a number of the rape cases were committed by APCLS combatants 'who targeted Mutongo villages in the forest after they had fled the fighting'.81 In detailing the sexual acts, the report noted that a majority of the victims were 'gang-raped by two to five combatants and were

78 Brownmiller 23.

79 Brownmiller 24.

80 See also P Worsnip 'UN's ban sends top aide to Congo after mass rape' Reuters Africa 24 August 2010.

81 UNJHRO Report (n 4 above) 15. 
reportedly targeted for belonging to the Nyanga ethnicity' (an ethnicity of the Mayi Mayi Sheka group).

(4) The final case reported is the Minova case file where between 15 November and 2 December 2012, a number of human rights and international humanitarian law violations occurred, including mass rape by the FARDC soldiers 'as they were retreating from the front lines and regrouping in and around the town of Minova, Kalehe territory, South Kivu province, following fighting with M23 combatants and their occupation of Goma and Sake, North Kivu' ${ }^{82}$ In this case, as many as 102 women and 33 girls were reportedly raped or sexually abused. From 20 November 2013, the Operational Military Court of North Kivu has been hearing the case of the FARDC, even though limited military judicial personnel have been working on the matter.

As demonstrated, Brownmiller's theory may fall short in the context of the DRC as a majority of the sexual abuse and rape cases have been without the necessary element of a 'victorious army'. Cohen, Green and Wood argue that there are a number of misconceptions regarding these theories, including the position that war time rape is common among rebel forces when compared to state militaries. ${ }^{83}$ Studies have shown that there is a greater possibility of state armed groups being the perpetrators of rape and sexual violence. The recent PRIO discourse of African conflicts noted that, between the years 2000 to 2009, there was a greater possibility of armed state actors being perpetrators than rebel or militia groups. The reason for this, according to Cohen, Green and Wood, remains unanswered. ${ }^{84}$ This premise is disturbing since states are mostly better trained and resourced when compared to rebel forces and, as such, both elements are thought to minimise the likelihood of sexual exploitation of noncombatants. ${ }^{85}$ What is suggested by the authors is that states tend to use sexual violence as a tool to torture detainees as well as civilians. ${ }^{86}$ Green contends that rape by states is used in the context of interrogations. ${ }^{87}$ Conversely, certain rebel groups require civilian support for resources (more than state forces) and are commonly fighting to become the new leaders of a country, factors that may make some types of rebel groups less likely to take advantage of civilian populations. This said, Cohen, Green and Wood argue that rebel groups, such as the $M 23$, use 'exploitative violence against civilians for a variety of reasons'. ${ }^{88}$

82 As above.

83 DK Cohen et al 'Wartime sexual violence: Misconceptions, implications and ways forward' United States Institute of Peace Special Report 323 (February 2013).

84 As above.

85 Cohen et al (n 83 above) 28.

86 As above.

87 JL Green 'Collective rape: A cross-national study of the incidence and perpetrators of mass political sexual violence, 1980-2003)' PhD thesis, Ohio State University, 2006.

88 Cohen et al (n 83 above) 4; see also J Weinstein Inside rebellion: The politics of insurgent violence (2006). 
Moreover, when examining sexual violence in the DRC, one may argue that marginalised males are eagerly attempting to retain their 'hegemonic constructions of masculinity'. ${ }^{89}$ This hegemonic construct is that of heterosexuality, and Hooper asserts that such forms of masculinity are linked to phallocentrism, and states that ${ }^{90}$

[b]oth the image of the penis as weapon and the conventional construction of heterosexual relations revolve around phallocentric discourse. Hegemonic masculinity, then, can be seen to be largely, but not exclusively, phallocentric.

Masculinity in the DRC is represented by a high sex drive, in order for the man to have multiple partners, to confer gifts in exchange for sexual favours, and to have the ability to financially purchase multiple wives. Such a view represents the need for a man to have the physical, social and economic ability to protect his wife from other men. ${ }^{91}$ However, a number of ethnic, cultural and, more importantly, socioeconomic elements exist that restrain them from achieving this premise. Banwell contends that subordinate or subsidiary masculinity evolves into a form of hypermasculinity, which is linked to elements of roughness, aggression and violence, and this form of masculinity 'offers these marginalised men the opportunity to take advantage of the chaos of war to challenge their marginal position within the gender hierarchy'. ${ }^{92}$ In addition, men in these scenarios can acquire symbolic 'rewards' (women) and wealth (minerals) in order to reestablish lost hegemony. In the context of the DRC, Baaz and Stern argue that for the FARDC, it was the 'failure' to retain the expectation of providing for their partners, and being sexually potent fighters, 'alongside negative and sexualised images of women, that led them to rape'. ${ }^{93}$ As such, one may argue that, in the context of the DRC, factors such as socio-cultural and socio-economic elements, as well as the notion of hegemonic masculinity, cause the region to be a breeding ground for rape and sexual violence becoming possible and justifiable. $^{94}$

In order to understand the complexities of the gender structure within the DRC, shame as an obstacle is also a cause for concern. Shame is considered one of the key obstacles to prosecution, with Goma Tribunal Militaire de Garnison Judge Solomon stating that 'sex is taboo, rape is dishonourable, and that one must hide $i^{\prime} .^{95}$ The Military Tribunal in Auditeur Militaire v Eliwo $\mathrm{Ngoy}^{96}$ held as follows: ${ }^{97}$

89 Banwell (n 12 above) 53.

90 Hooper (n 62 above) 59-60.

91 As above.

92 As above.

93 Banwell (n 12 above) 53.

94 As above.

95 Mansfield (n 6 above) 387.

96 RP n 084/2005 RMP n 154/PEN/SHOFO5.

97 As above. 
Sexual assault is one of the most difficult things to report because of the socio-cultural context [of Congo]. In almost all societies, a woman, a man or a child making allegations of rape, sexual violence or mutilation, has much to lose and risks being the object of tremendous pressure and ostracism on the part of his or her immediate family members and the community in general.

Rape is viewed as dishonourable, with many husbands refusing to continue to live with a wife who has been raped. Consequently, women lose their husbands because of the stigma associated with being raped. When speaking to a rape victim, Mansfield asked whether they would assist in initiating proceedings against the rapist, and she responded by saying that '[t]hey wouldn't accompany me. They don't love me; they've abandoned me since the rape. ${ }^{\prime 98}$ This leads one to believe that ostracism by the community is a further psychological obstacle associated with this element. Such ostracism may lead to police lacking the necessary skills and sensitivities to conduct and assist in investigations. The justice system lacks the tools to ensure confidentially and the anonymity of rape victims and witnesses, and this creates the further dilemma of causing women to be reluctant to discuss their experiences in front of male officers. Engle and Lottman contend that criminal justice may be viewed as a means for attacking shame, with Nowrojee asserting that criminal liability is therapeutic for victims, by noting that the ability of the victim to hold the perpetrator responsible is an aspect of healing. ${ }^{99}$ The future of the criminal justice system in the DRC is uncertain and the establishment of more concrete judicial infrastructures would further be seen as one of the remedies to the overarching problem of rape as a weapon of war, contributing also to positively influencing the gender-based arguments around the subject.

The conceptualisation of sexual violence in the DRC as a 'weapon of war' has both merits and challenges. Trends of rape in the region demonstrate the complex web around the subject. Baaz and Stern articulate the importance of the action regardless of the victim's political or ethnic affiliation to the perpetrator. Whether used as a military strategy, as a form of cultural humiliation or social intimidation, the prosecution of sexual violence is challenged due to the weak judicial infrastructure and correctional system in the DRC. A questionable judicial system, therefore, leads to the possibility of a specialised chamber, which is considered in the section below.

\section{Establishment of a specialised chamber in the DRC}

The DRC has been the 'face' of serious violations of international humanitarian and human rights law, with the International Criminal Court (ICC) opening investigations in the region in 2004.

98 Mansfield (n 6 above) 388.

99 Engle \& Lottman (n 11 above). 
Consequently, the urge to hold those accountable remains 'tremendous and national authorities retain the primary obligation to bring to justice those responsible ${ }^{100}$ for crimes under the Rome Statute. Further, the judicial system seems to be fundamentally flawed with its underfunded administration, lack of sustainable regulation and its interference by both the political and military hierarchy in the region. ${ }^{101}$ In 2008, the United Nations Independent Expert on the Situation of Human Rights in the Democratic Republic of the Congo reported that 'little progress has been made to date with regard to the administration of justice and the fight against impunity, and thus it seems that a climate of virtually generalised impunity persists throughout the Democratic Republic of the Congo'. ${ }^{102}$ The DRC issued draft legislation allowing the implementation of its obligations under the Rome Statue and, therefore, giving the ICC the power to extend its jurisdiction for crimes within the statute to civilian courts. ${ }^{103}$ The DRC Parliament adopted draft legislation implementing the Rome Statute in December 2013.104

Since 2004, numerous legal experts, NGOs and Congolese civil society organisations have suggested the establishment of a specialised mixed chamber or, in some cases, special international or hybrid tribunals to try individuals accused of crimes under the Rome Statute. ${ }^{105}$ Understanding the distinctions between these, however, is critical to arguing which form of judicial authority would best address the needs in the country. The distinction is clear: Mixed chambers possess a national judicial framework with the inclusion of temporary international staff, ${ }^{106}$ whereas hybrid tribunals have effective efforts by both the international community and national institutions, utilise both national and international judicial actors as well as incorporate the sophistication of both domestic and international law in their statutes. ${ }^{107}$

100 Human Rights Watch 'Accountability for atrocities committed in the Democratic Republic of Congo: Supporting the government's proposal to establish specialised mixed chambers and other related judicial reform' April 2014.

101 Rebuilding Courts and Trust: An Assessment of the Needs of the Justice System in the Democratic Republic of Congo, Report for the International Legal Assistance Consortium and International Bar Association Human Rights August 2009.

102 Report of the Independent Expert on the Situation of Human Rights in the Democratic Republic of the Congo 29 February 2008 UN Doc A/HRC/7/25 para 5.

103 S Willis Hybrid and internationalised criminal tribunals: Selected jurisdictional issues (2012) 157.

104 Adopted by the National Assembly's Commission on Politics, Administration and Justice.

105 Human Rights Watch 'Tackling impunity in Congo: Meaningful follow-up to the UN mapping report: A mixed chamber and other accountability measures' October 2010.

106 Human Rights Watch 'DR Congo: A "mixed chamber" for Congo?' 5 October 2009.

107 D Cohen 'Hybrid justice in East Timor, Sierra Leone, and Cambodia: "Lessons learned" and prospects for the future' (2007) 43 Stanford Journal of International Law 12. 
Further, the United Nations Office of the High Commissioner for Human Rights released a mapping report outlining human rights violations between 1993 and 2003 and concluded that, despite several attempts at reforming the DRC's judicial framework, the system as it stands has 'neither the capability nor the credibility required in order to step up efforts to the fight against impunity for the many violations of fundamental rights committed ... in the past'. ${ }^{108}$ There are a number of reasons for the possible implementation of a specialised mixed chamber in the DRC:

(1) The creation of this chamber would be consistent with the DRC's primary obligations under international law when trying offenders in the region.

(2) The chamber would be incorporated into existing efforts to amend the current legal and judicial system and, as such, it would assist to develop expertise at the local level.

(3) A mixed chamber could be established within a short timeframe with fewer financial implications.

(4) International involvement in key posts would offer greater guarantees of impartiality and independence and thus have greater credibility. ${ }^{109}$

(5) The Congolese would claim ownership of the process as well as the institution. What has been seen as an impediment to the fight against impunity is the lack of independence of the DRC's judiciary, and the ability of non-Congolese staff to be present would assist in 'buffering the chambers from interference from the executive and the military hierarchy'.110

(6) There is the possibility for the DRC to become an open-ended territorial jurisdiction.

The development of such a system also has its complications and challenges. The mapping report outlines the following challenges: ${ }^{12}$

(i) the lack of credibility of the national judicial system in the eyes of the Congolese people ...;

(ii) the chronic lack of capacity in the Congolese judicial system could endanger this new mechanism ... The judicial system in the DRC suffers from a significant lack of structures, financial and operational resources, human resources and general capacity to enable all those involved in it to fulfil their functions adequately and be sheltered from financial concerns. Significant and consistent support from the international community would be essential for the success of such a mechanism, both in terms of the initial set-up and its ongoing operation.

(iii) It would be more difficult to ensure that third party states would cooperate with these new chambers, given that they would be under no general obligation to collaborate and would probably be more

108 OHCHR 'Democratic Republic of the Congo - 1993-2003' Report of the Mapping Exercise Documenting the Most Serious Violations of Human Rights and International Humanitarian Law Committed within the Territory of the Democratic Republic of the Congo between March 1993 and June 2003, August 2010 para 979.

109 Willis (n 103 above).

110 As above.

111 OHCHR (n 108 above) paras 1043-1046.

112 OHCHR para 1045. 
reticent to co-operate with them than they would be towards an international body independent of the Congolese judicial system.

The suggested alternative of a hybrid model, based on that of the Special Court for Sierra Leone, ${ }^{113}$ was deemed to be unsuitable due to the lengthy timeframe of it being established, in addition to a possible treaty being required between the UN and the DRC. It was also viewed as an 'ad hoc institution, with little impact on wider issues of impunity and capacity building within the DRC, and would involve a greater impact on the sovereignty of the DRC, ${ }^{\prime 114}$ as the DRC would need to give jurisdiction in criminal matters (of its own nationals) to an independent international court. In addition, the Special Court for Sierra Leone created unrealistic expectations, and it is this 'legacy' that warrants scholars and practitioners to question the benefit of a hybrid court in the DRC. On this note, it may be argued that what is mostly criticised about international tribunals is the fact that they neglect to assist with national reconciliation in a country and, therefore, they rarely contribute to the reinstitution of the rule of law after a conflict. 115

A mixed chamber gives civil society confidence that it would counter this notion due to its functioning and existing within the conflict-pressured society. Research conducted by the United Nations Development Programme, together with the International Centre for Transitional Justice, specified that the majority of Sierra Leoneans believed that the Court did justice to the region by leaving a more prominent legacy rather than prosecuting a number of individuals. ${ }^{116}$ In addition, the ideals provided by establishing such a framework also led a number of people to believe that the court would 'contribute to institution building ... helping to rebuild a shattered judiciary, revitalise legal education, and assist in legal reform even as it is expected to contribute to reconciliation'. ${ }^{119}$ Whether the court has the ability to support capacity building is debatable due to the limited resources provided.

With regard to the prospect of the court rebuilding a dysfunctional judicial system, it is argued that having the court as an entity separate from the domestic system creates concerns for practitioners and members of the court. This concern is that there will be no legacy and that such a legacy assists in strengthening the domestic legal and

113 The Special Court was officially established by a bilateral agreement between the government of Sierra Leone and the United Nations that was signed in the Sierra Leonean capital, Freetown, on 16 January 2002. Act 9, Special Court Agreement, 2002 (Ratification Act).

114 Willis (n 103 above) 159. See also UNHRC 'The human rights situation in the Democratic Republic of the Congo and the strengthening of technical cooperation and advisory services' 21 March 2011 UN Doc A/HRC/RES/16/35 para 6.

115 CL Sriram 'Wrong-sizing international justice? The hybrid tribunal in Sierra Leone' (2005) 29 Fordham International Law Journal 472490.

116 Sriram (n 115 above) 497.

117 Sriram 498. 
judicial system. In the context of Sierra Leone, this is viewed as critical since the domestic judicial system lacks a number of fundamental elements, such as law reports and decisions previously handed down. Sierra Leone has a resemblance to the DRC in that its system is scoured with corruption, financial challenges and bribery. ${ }^{118}$ Such issues create a cause for concern where both states are attempting to create judicial independence, something that is currently far from being achieved.

Informing the wider community is also a mandate that needs to be focused on when establishing these tribunals. In the case of the Special Court for Sierra Leone, a number of court staff members have engaged with the public in order to provide information and to develop basic legal capacity to have society use the Court to its full potential. There has been some scepticism regarding the relationship between the Court and national justice mechanisms, because of the Court enticing a number of legal experts away from current or future roles in the national legal system. ${ }^{119}$ In addition, the Court has 'taken land from the prison service, including land intended for a new training school'. ${ }^{20}$

In an effort to make the work of the Court appealing and comprehensible, outreach staff have attempted to develop training programmes for local chiefs and community leaders by linking international legal standards of due process to domestic and traditional mechanisms of justice, as well as the rule of law. ${ }^{121}$ Such collaboration would seek to benefit the mixed chambers approach in the DRC, as a number of cultural and traditional judicial standards are still held in the eastern province. In addition, the majority of both Congolese and Sierra Leoneans are 'little affected by the formal legal sector', yet still partake in and follow traditional frameworks. However, certain scholars ${ }^{122}$ argue that a more appropriate way of addressing crimes of the past would be through traditional avenues, including 'purification and cleansing ceremonies, and certainly that at the very least these traditional activities ought to supplement more formal ones'. ${ }^{123}$ Moreover, a number of international and external actors involved in the functions of the court note their eagerness for the court to have an impact on victims and the wider community, something that can be seen in other mixed tribunals. ${ }^{124}$ There have, however, been 'negative effects on local capacity, and outreach is as

118 Sriram 499.

119 As above.

120 As above.

121 As above.

122 Sriram interviewed Alfred Carew, head of the National Forum for Human Rights, Freetown, 15 July 2004, See A-S Rodella 'Justice, peace, and reconciliation in postconflict societies: The case of Sierra Leone' Fletcher School, Tufts University, May 2003.

123 As above.

124 As above. See also C Schocken 'The Special Court for Sierra Leone: Overview and recommendations' (2002) 20 Berkley Journal of International Law 436452. 
yet limited' ${ }^{125}$ One may argue that the court is not to be viewed as a building mechanism for national legal capacity, and that such an idea should be further critiqued. Only if the court side-tracks its attention and use of resources form other domestic needs should concerns arise within the domestic and international context.

The establishment of a mixed special chamber provides victims of sexual violence and extreme violations of their human rights, with the ability to fight impunity and to seek justice. In addition, its inclusion in the Congolese judicial system would directly assist in creating capacity-building initiatives which would develop safeguards that would protect it from being undermined by the DRC's political and military elite. However, significant endeavours would need to be made in order to guarantee credibility. ${ }^{126}$

\section{The way forward: Combating sexual violence in the DRC by addressing existing obstacles}

Combating sexual violence and addressing impunity require a number of obstacles to be removed. Arguably, the problem with prosecuting those who commit sexual violence in the DRC is not institutional, legal or sociological, but rather the pervading existence of insecurity in the region. The unrelenting insecurity facilitates the commission of rape, which causes a number of obstacles to justice. ${ }^{127}$ Mansfield contends that the continued fighting in Eastern DRC has severely affected health services for rape victims, diverting attention away from prosecuting those involved. ${ }^{28}$ Health services may be challenged, given the large number of rape victims requiring attention, as well as fighting affecting the actual clinics. As such, reforming the security dimension of the crisis is viewed as one of the fundamental dimensions to sexual violence. The Enough Project of John Predergast argues that ${ }^{129}$

... deal[ing] with rape as a weapon of war in isolation will fail and fail miserably. If we truly want to end this scourge we must move from managing conflict symptoms to ending the conflicts themselves.

125 As above.

126 OHCHR (n 108 above) 1046

127 Mansfield ( $\mathrm{n} 6$ above) 404.

128 As above. Mansfield argues that due to the constant insecurity within the region, 'facilitates the commission of rapes ... [and] also causes several obstacles to prosecuting sexual violence perpetrators', therefore creating a number of obstacles towards both the notion of justice and the Congolese justice system.

129 As above. See Enough Project John Prendergast 'Confronting rape and other forms of violence against women in conflict zones - Spotlight: DRC and Sudan' 13 May 2009. 
Mansfield and Zongwe continue to argue that the DRC is the only country in the region that has its peace and stability in the hands of regional diplomatic relations. ${ }^{130}$ One may, therefore, argue that in order to achieve stability and security, it is crucial to solidify regional military co-operation. This would allow neighbouring states, such as Uganda and Rwanda, to dispose of rebel forces and to 'extinguish the remaining pockets of insecurity in Eastern DRC and the entire Great Lakes region' ${ }^{131}$ In addition, the adoption of measures to stop the illegal trade in minerals must be implemented not only by the United Nations and international bodies, but should be driven by the Congolese government. This can be achieved by increasing security within mining districts. The international community should also insist upon accountability in the regulation of multinational corporations, in order to ensure that the minerals being traded do not emanate from armed and bloody conflicts. ${ }^{132}$

Moreover, with regard to combating impunity through justice, the DRC is facing a crisis due to corruption within its judicial and political system. Peace and justice will never be possible while arrests are being neglected, convictions set aside and perpetrators are escaping. The UN Security Council affirmed in Resolution 1820 that 'effective steps to prevent and respond to acts of sexual violence can significantly contribute to the maintenance of international peace and security'. ${ }^{133}$ A current issue is the strategy necessary to assist with gender justice. As indicated previously, the establishment of a special mixed chamber would assist in combating this element. The model of transitional justice would be built on international support with the premise of building on the existing Congolese framework. Further, the Congolese government should also be required to continue to improve its domestic legal system in order to strengthen judicial institutions when combating sexual violence. Training specialised investigators, providing greater access to justice for victims and enforcing judgments (that is, ensuring reparation payments in addition to the imprisonment of those convicted) would assist with the process of combating sexual violence.

Importantly, however, gender must be seen at the forefront of these frameworks. It may be argued that international humanitarian law needs to be reviewed in order for a feminist order building to exist which focuses on punishing those who commit sexual violence against women. The criminal process should have a platform to allow women to tell their stories rather than to have these edited based on a

130 As above. See also DP Zongwe 'The legal justifications for a people-based approach to the control of mineral resources in the Democratic Republic of the Congo' 26 April 2008 Cornell Law School Inter-University Graduate Student Conference Paper 12 http://scholarship.law.cornell.edu/lps-clacp/12 (accessed 18 December 2015).

131 Zobgwe (n 130 above) 405.

132 As above.

133 UNSC Resolution 1820 (2008) of 19 June 2008. 
patriarchal legal framework. Dixon ${ }^{134}$ and Mertus ${ }^{135}$ arque this point, with Mertus focusing on the Foca case, contending that ${ }^{136}$

[t]he witnesses almost universally experience the trials as dehumanising and re-traumatising experiences ... the narrative of the witness is contorted to suit the needs of the audience.

Consequently, the process suppresses women's stories and disempowers them in their time of need. The framework, therefore, has to make it clear that women's experiences are fully recognised by the legal system and, as such, women and gender are put first.

Moreover, with regard to gender maintenance in the legal system, Mansfield suggests that the state should persuade traditional chiefs to assist former soldiers, rape survivors and (certain) sexual offenders to reintegrate into their respective traditional communities. ${ }^{137}$ Nevertheless, there is also the international requirement for the state to protect the rights of women, which 'implies developing customary law and circumscribing the criminal jurisdiction of traditional courts as certain aspects of customary laws discriminate against women'. ${ }^{138}$ The state must, therefore, implement a legislative framework that defines the jurisdictional limits of traditional courts in order for them to comply with gender rights and international standards. Mansfield argues that ${ }^{139}$

[c]ustomary prosecutions can remove obstacles to the effective and successful prosecution of sexual violence, namely, acceptance by the people of prosecution as an effective remedy, a lack of knowledge of state laws, shame, costs, distance, fear of the judicial process, evidence, long delays, corruption and enforcement.

Furthermore, Mansfield argues that a distinction is required in order to distinguish between statutory rape and violent rape against minors. The equal treatment of both these forms of rape 'inflates official rape prosecution statistics and leads one to an inaccurate perception of the number of violent rape cases handled by the courts'. ${ }^{140}$ One may, therefore, argue that this is critical as it convolutes the assessment of the severity of sexual violence in the region, in addition to the 'urgency of measures needed to respond'. ${ }^{14 \mathrm{~T}}$

134 R Dixon 'Rape as a crime in international humanitarian law: Where from here?' (2002) 13 European Journal of International Law 697.

135 J Mertus 'Shouting from the bottom of the well: The impact of international trials for wartime rape on women's agency' (2004) 6 International Feminist Journal of Politics 110.

136 Mertus (n 135 above) 112.

137 Mansfield (n 6 above) 408.

138 As above.

139 As above.

140 As above.

141 As above. 


\section{Conclusion}

Crimes of sexual violence continue to occur, perpetrated by armed groups as well as members of the military and the police force. Sexual violence is punishable under Congolese national law as well as in terms of international legal obligations. However, the system that was built to protect civil society is flawed, and limited progress has been made with combating impunity. Outlined above are a number of cases that clearly demonstrate that sexual violence is on the rise in the DRC. A number of obstacles exist, with many cases not being investigated; perpetrators not being prosecuted due to, for example, limited efforts by the Congolese authorities to prosecute crimes of sexual violence; a corrupt judiciary; issues of domestic infrastructure; and traditional and cultural values. These obstacles and failures emphasise the notion that rape is a weapon of war, especially in the context of the DRC. The article has assisted in viewing rape and sexual violence as a key to understanding aspects of armed conflict.

The issue of militarised groups being the hub for men learning to associate violence with masculinity was also critiqued. As argued in the article, militarised masculinity and heterosexuality must be understood as institutionalised issues. ${ }^{142}$ While there may be no single measure that will put an end to sexual violence in the DRC, an analysis of the situation in the region led the article to make recommendations on combating sexual violence and impunity. Noting this importance, I also argued the position that a specialised mixed chamber should be established for the DRC, and made a comparison between the idea of a mixed chamber and the reality of an existing hybrid court, namely, the Special Court for Sierra Leone. Evidently, the premise of the analysis was that the establishment of an international judicial body for the DRC would offer more grounded guarantees of success, as well as assist in strengthening the DRC's national system that is infected by political corruption.

142 Banwell (n 12 above) 56. 